\title{
Modeling and Simulation on Batch Phase of Pathogen Transport in Short Fresh Water Aquifers in Heterogeneous Sand Gravel in Coastal Area of Abonnema, Rivers State of Nigeria
}

\author{
Eluozo S. N. \\ Department of Civil and Environmental Engineering, Subaka, Nigeria
}

Email address:

Soloeluozo2013@hotmail.com, solomoneluozo2000@yahoo.com

To cite this article:

Eluozo S. N. Modeling and Simulation on Batch Phase of Pathogen Transport in Short Fresh Water Aquifers in Heterogeneous Sand Gravel in Coastal Area of Abonnema, Rivers State of Nigeria. Journal of Health and Environmental Research. Vol. 3, No. 2, 2017 , pp. $31-36$. doi: $10.11648 /$ j.jher.20170302.13

Received: October 26, 2016; Accepted: January 6, 2017; Published: March 17, 2017

\begin{abstract}
This paper evaluated the application of Batch phase system on the migration and deposition process of pathogen in coastal area of Abonnema, this is to monitored the behaviour of the pathogenic origin in predominant saline environment, the study location deposited shallow short fresh water aquifers in the region, the study areas developed homogeneous deposited Aquiferous zone at shallow and deep formation, whereby deep Aquiferous is capital intensive to exploit, base on these conditions, majority of human settlers resolved in developing ground water at shallow Aquiferous zone, it has been confirmed that the deposition of pathogen are from human activities that has polluted shallow Aquiferous zone to the maximum level due to its high rate of porous medium. The rate of concentration between predictive and experimental values range from 9.57E-05$1.46 \mathrm{E}-03,9.37 \mathrm{E}-05-1.46 \mathrm{E}-03$ between the depth of $0.2-3 \mathrm{~m}$ deep, while for time of transport ranged from $0.016-0.24 \mathrm{~m} 0.016-$ 0.21 , at the period of 2 to 24 days, monitoring the rate of concentration were carried out through mathematical modeling by developing a system that express all the functional influential parameters, the developed model were simulated to express the behaviour of the pathogen in saline environment, the theoretical model values generated from the simulation were compared with measured values from column experiment, both parameters generated favorable fits validating the model, experts will find the developed model a useful tool in monitoring the migration of pathogen in homogeneous sand gravel formation in coastal area of Abonnema.
\end{abstract}

Keywords: Modeling and Simulation, Batch Phase of Pathogen, and Homogeneous Sand Gravel

\section{Introduction}

Groundwater may be contaminated, when wastewater infiltrates into the soil and recharges groundwater via leaking sewerage systems, leakage from manure, wastewater or sewage sludge spread by farmers on fields, waste from animal feedlots, waste from healthcare facilities, leakage from waste disposal sites and landfills, or artificial recharge of treated waste water. If the distance from source of pollution to point of abstraction is small, there is a real chance of abstracting pathogens. To predict the presence of pathogens in water, usually a separate group of microorganisms is used. The common descriptive term for this group of organisms is fecal indicator organisms [6], from which Escherichia coli (or E. coli) and Thermotolerant coliform bacteria are two important members. E. coli is widely preferred and used as an index of fecal contamination [13], because its detection is relatively simple, fast and reliable, and the organism is routinely measured in water samples throughout the world. The same applies to Thermotolerant ('fecal') coliform. These coliforms are a less reliable index of fecal contamination than E. coli, although under most circumstances their concentrations are directly related to $E$. coli concentrations [13]. Virus may be considered more critical to groundwater quality than E. coli. Because of their smaller size, stability, and negative charge, they may be transported even further through the ground, and because of their infectiousness they represent a major threat to 
public health CFT is a commonly used approach for describing attachment of E. coli in saturated porous media [5-9], and since a part of this research is using the CFT as starting point, the theory will be briefly explained here. The one-dimensional macroscopic mass balance equation for mobile bacteria suspended in the aqueous phase without the interference of biological factors such as growth and decay can be expressed as [2-4]: Because of heterogeneity among members of the bacteria population, deposition of bacteria may change upon the distance bacteria are transported in an aquifer. These deposition variations can have a profound effect on the distances $E$. coli can travel in the subsurface [1, 10 -12], and therefore deposition variations of $E$. coli were examined in columns of sodalimeglass beads of various sizes. In addition, column experiments were carried out to confirm the presence of subpopulations of bacteria causing deposition variations. To predict the presence of pathogens in water, a separate group of microorganisms is usually used, generally known as fecal indicator organisms [5-7]. Many microorganisms have been suggested as microbial indicators of fecal pollution (like Enterococci, coliphages and sulphite reducing clostridia spores; [1-5], but two of the most important indicators used worldwide are Escherichia coli and Thermotolerant coliform bacteria (for microbiological definitions of these indicators,). Both are widely used, because their detection is relatively simple, fast, and reliable. E. coli is the preferred indicator of fecal contamination, as it is the only member of the Thermotolerant coliform group that is invariably found in feces of warmblooded animals and it out numbers the other Thermotolerant coliform in both human and animal excreta [6]. Thermotolerant coliform are a less reliable index of fecal contamination than E.coli, although under most circumstances their concentrations are directly related to $E$. coli concentrations [8]. Viruses may be considered as the most critical or limiting microorganism. Because of their small size, their mostly negative surface charge, and their high persistence in the environment, they may travel long distances in the subsurface. In addition, they can be highly infectious [10-14] in the study [4].

Theoretical Background

Unconfined beds are formations that are deposited in coastal area of Abonnema, Rivers State of Nigeria. The structures strata developed unconfined bed developing alluvium deposited in predominant sand gravel formation. The stratification setting predominantly deposit under the influence of alluvium deposition predominated known to develop its strata structure by sea deposition. Such geological origins were always known to deposit homogeneous structure even if it is lies under Benin formation. Discovering high rate of alluvium deposition of sand gravel that structures homogeneous in every region of Abonnema settlements, it was confirmed from hydrogeological studies to deposit homogeneous sand gravel with overlap deposition by deltaic clay. These were influenced by high degree of porosity that established an interaction with dispersion rate under the influence of the microspores of deposited strata. E.coli through human excretes were found to deposit shallow unconfined beds from fine to sand gravel sand. Such microbial depositions were found to establish a reaction with other deposited substances. These circumstances subject the deposition of minerals to establish a fluctuation of inhibition. Subject to this interaction, the established reactions between the two parameters leads to fluctuation in the water quality of semi confined beds. Dispersion influence was found to deposit through high percentage of porosity in the strata dispersing potassium and lead in semi confined beds. These have generated high spread of the pollutants in the region to unconfined beds. Subject to these challenges, better solutions to prevent further migration or dispersion of this contaminant should be developed. In line with these factors, mathematical model were found appropriate to express divergent influences and ways of preventing such contamination. These factors are considered where a system that captured every parameters were recorded, these circumstances was considered and it generate the governing equations stated below

\section{Governing Equation}

$$
K \frac{\partial^{2} c}{\partial t^{2}}=D \frac{\partial c}{\partial Z}-U \lambda \frac{\partial c}{\partial Z}
$$

$\begin{array}{ll}\text { Nomenclature } & \\ \mathrm{C}=\text { pathogen concentration } & {[\mathrm{ML}-3]} \\ \lambda=\text { Saline concentration } & {[\mathrm{ML}-3]} \\ \mathrm{K}=\text { Permeability } & {\left[\mathrm{LT}^{-1}\right]} \\ \mathrm{U}=\text { Velocity } & {\left[\mathrm{LT}^{-1}\right]} \\ \mathrm{T}=\text { Time } & {[\mathrm{T}]} \\ \mathrm{Z}=\text { Depth } & {[\mathrm{L}]}\end{array}$

Let $C=T, Z$

$$
\begin{gathered}
K T^{11} Z=D T Z^{1}-U \lambda T Z^{1} \\
K \frac{T^{11}}{T}=D \frac{Z^{1}}{Z}-U \lambda \frac{Z^{1}}{Z} \\
K \frac{T^{11}}{T}=\theta^{2} \\
D \frac{Z^{1}}{Z}=\theta^{2} \\
-U \lambda \frac{Z^{1}}{Z}=\theta^{2} \\
{[D-U \lambda] \frac{Z^{1}}{Z}=\theta^{2}} \\
K \frac{d c}{d t}=\theta^{2} \\
K \frac{d c^{2}}{d t^{2}}=\theta^{2}
\end{gathered}
$$




$$
\begin{aligned}
& D \frac{d c}{d Z}=\theta^{2} \\
& -U \lambda \frac{d c}{d Z}=\theta^{2} \\
& d^{2} Z=\left[\frac{\theta^{2}}{K}\right]=d Z \\
& \int d^{2}=\int \frac{\theta^{2}}{K} d Z \\
& d Z=\frac{\theta^{2}}{K} Z+C_{1} \\
& \int d Z-\int \frac{\theta^{2}}{K} Z d Z+C_{1} \int d Z \\
& Z=\frac{\theta^{2}}{K} \frac{Z^{2}}{2}+C_{1}+C_{2} \\
& Z=\frac{\theta^{2}}{K} \frac{Z^{2}}{2}+C_{1^{2}}+C_{2} \\
& Z=\frac{\theta^{2}}{K} Z^{2}+C_{1^{2}}+C_{2} \\
& \Rightarrow \frac{\theta^{2}}{2 K} Z^{2}+C_{1^{2}}+C_{2}=0
\end{aligned}
$$

Auxiliary equation becomes

$$
\frac{\theta^{2}}{2 K} M_{2}+C_{2} M+C_{2}=0
$$

Applying quadratic expression, we have

$$
\begin{aligned}
& M_{1^{2}}=\frac{-b \pm \sqrt{b^{2}-4 a c}}{2 a} \\
& M=\frac{-C_{1} \sqrt{C^{2}-4 \frac{\left(\theta^{2}\right)}{2 K} C_{2}}}{2 \frac{\theta^{2}}{K}} \\
& M_{1}=\frac{-+C_{1} \sqrt{C^{2}-2 C_{2} \frac{\theta^{2}}{K}}}{2 \frac{\theta^{2}}{K}} \\
& M_{2}=\frac{-C-\sqrt{C_{1}^{2}-2 C_{2} \frac{\theta^{2}}{K}}}{2 \frac{\theta^{2}}{K}}
\end{aligned}
$$

Assuming this discriminate is complex, therefore equation (23) and (24) can be written as:

$$
C[T, Z]=F 1 \operatorname{Cos} M_{1} t+F 2 \operatorname{Sin} M_{2} Z
$$

But if But if $t=\frac{d}{v}$ and $Z=v \cdot t$

The expressed model can be written as

$$
C[T, Z]=F 1 \operatorname{Cos} M_{1} \frac{d}{v}+F 2 \operatorname{Sin} M_{2} V \cdot t
$$

\section{Material and Method}

Column experiments were also performed using soil samples from several different borehole locations, the soil samples were collected at intervals of three metres each $(3 \mathrm{~m})$. Pathogen solute was introduced at the top of the column and effluents from the lower end of the column were collected and analyzed for pathogen and the effluent at the down of the column were collected at different days, analysis. This experiment were performed to compare with the theoretical values from the developed model for validation

\section{Results and Discussion}

Results and discussion are presented in tables including graphical representation of E.coli system condition

Table 4.1. Theoretical vales of pathogen at Different Depth.

\begin{tabular}{ll}
\hline Depth [m] & Theoretical Values Conc. \\
\hline 0.2 & $9.75 \mathrm{E}-05$ \\
0.4 & $1.95 \mathrm{E}-04$ \\
0.6 & $2.92 \mathrm{E}-04$ \\
0.8 & $3.90 \mathrm{E}-04$ \\
1 & $4.87 \mathrm{E}-04$ \\
1.2 & $5.85 \mathrm{E}-04$ \\
1.4 & $6.82 \mathrm{E}-04$ \\
1.6 & $7.80 \mathrm{E}-04$ \\
1.8 & $8.77 \mathrm{E}-04$ \\
2 & $9.75 \mathrm{E}-04$ \\
2.2 & $1.07 \mathrm{E}-03$ \\
2.4 & $1.17 \mathrm{E}-03$ \\
2.6 & $1.26 \mathrm{E}-03$ \\
2.8 & $1.36 \mathrm{E}-03$ \\
3 & $1.46 \mathrm{E}-03$ \\
\hline
\end{tabular}

Table 4.2. Theoretical and Measured values of pathogen Concentration at Different depth.

\begin{tabular}{lll}
\hline Depth $[\mathrm{m}]$ & Theoretical Values Conc. & Measured values \\
\hline 0.2 & $9.75 \mathrm{E}-05$ & $9.37 \mathrm{E}-05$ \\
0.4 & $1.95 \mathrm{E}-04$ & $1.88 \mathrm{E}-04$ \\
0.6 & $2.92 \mathrm{E}-04$ & $2.88 \mathrm{E}-04$ \\
0.8 & $3.90 \mathrm{E}-04$ & $3.80 \mathrm{E}-04$ \\
1 & $4.87 \mathrm{E}-04$ & $4.56 \mathrm{E}-04$ \\
1.2 & $5.85 \mathrm{E}-04$ & $5.55 \mathrm{E}-04$ \\
1.4 & $6.82 \mathrm{E}-04$ & $6.77 \mathrm{E}-04$ \\
1.6 & $7.80 \mathrm{E}-04$ & $7.66 \mathrm{E}-04$ \\
1.8 & $8.77 \mathrm{E}-04$ & $8.55 \mathrm{E}-04$ \\
2 & $9.75 \mathrm{E}-04$ & $9.72 \mathrm{E}-04$ \\
2.2 & $1.07 \mathrm{E}-03$ & $1.09 \mathrm{E}-03$ \\
2.4 & $1.17 \mathrm{E}-03$ & $1.15 \mathrm{E}-03$ \\
2.6 & $1.26 \mathrm{E}-03$ & $1.25 \mathrm{E}-03$ \\
2.8 & $1.36 \mathrm{E}-03$ & $1.34 \mathrm{E}-03$ \\
3 & $1.46 \mathrm{E}-03$ & $1.46 \mathrm{E}-03$ \\
\hline
\end{tabular}


Table 4.3. Theoretical vales of pathogen at Different Depth.

\begin{tabular}{ll}
\hline Time Per Day & Theoretical values \\
\hline 2 & 0.016 \\
4 & 0.032 \\
6 & 0.049 \\
8 & 0.065 \\
10 & 0.081 \\
12 & 0.098 \\
14 & 0.11 \\
16 & 0.13 \\
18 & 0.14 \\
20 & 0.16 \\
22 & 0.18 \\
24 & 0.196 \\
26 & 0.21 \\
28 & 0.22 \\
30 & 0.24 \\
\hline
\end{tabular}

Table 4.4. Theoretical Measured values of pathogen Concentration at Different depth.

\begin{tabular}{lll}
\hline Time Per Day & Theoretical values & Measured Values \\
\hline 2 & 0.016 & 0.016 \\
4 & 0.032 & 0.032 \\
6 & 0.049 & 0.048 \\
8 & 0.065 & 0.064 \\
10 & 0.081 & 0.08 \\
12 & 0.098 & 0.096 \\
14 & 0.11 & 0.112 \\
16 & 0.13 & 0.128 \\
18 & 0.14 & 0.144 \\
20 & 0.16 & 0.16 \\
22 & 0.18 & 0.176 \\
24 & 0.196 & 0.192 \\
26 & 0.21 & 0.208 \\
28 & 0.22 & 0.22 \\
30 & 0.24 & 0.24 \\
\hline
\end{tabular}

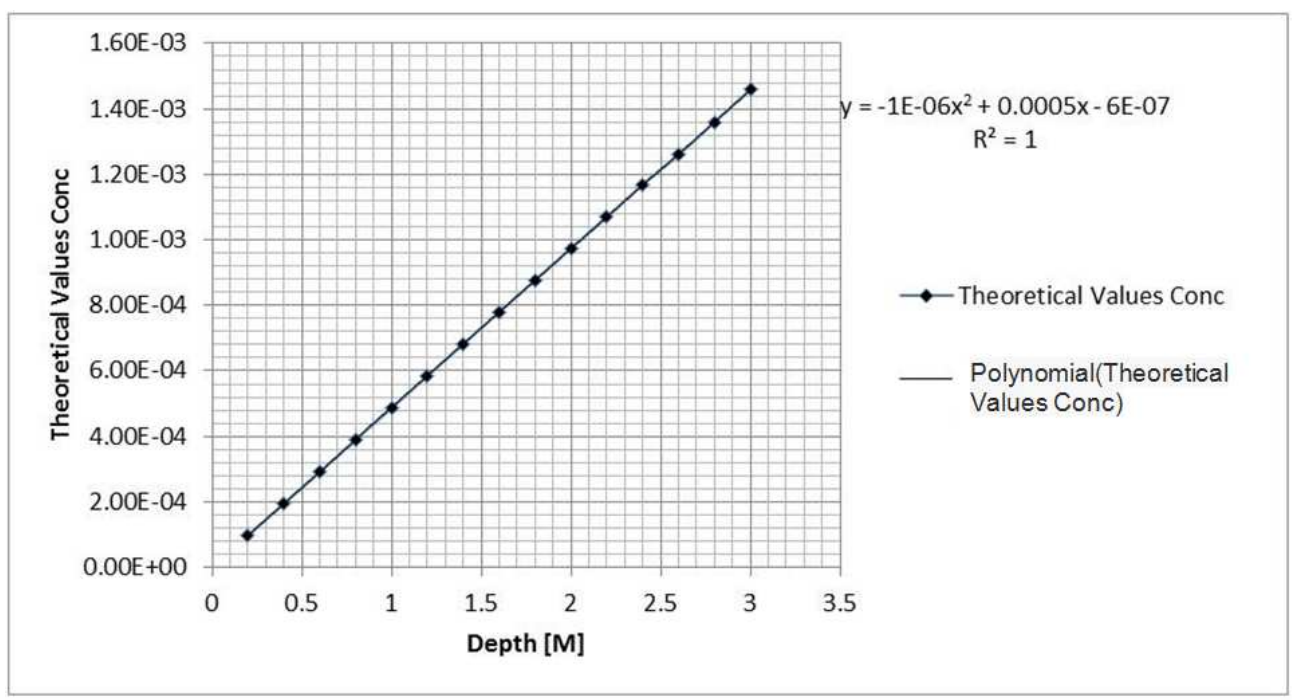

Figure 4.1. Theoretical vales of pathogen at Different Depth.

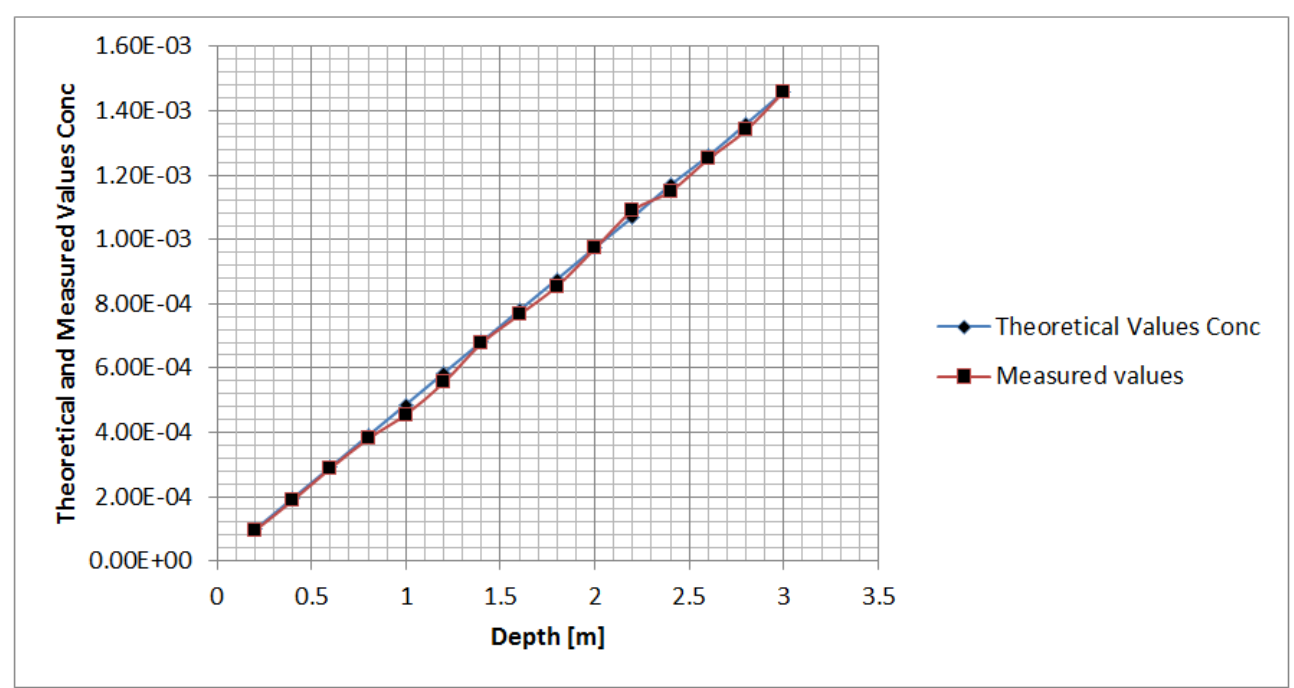

Figure 4.2. Theoretical Measured values of pathogen Concentration at Different depth. 


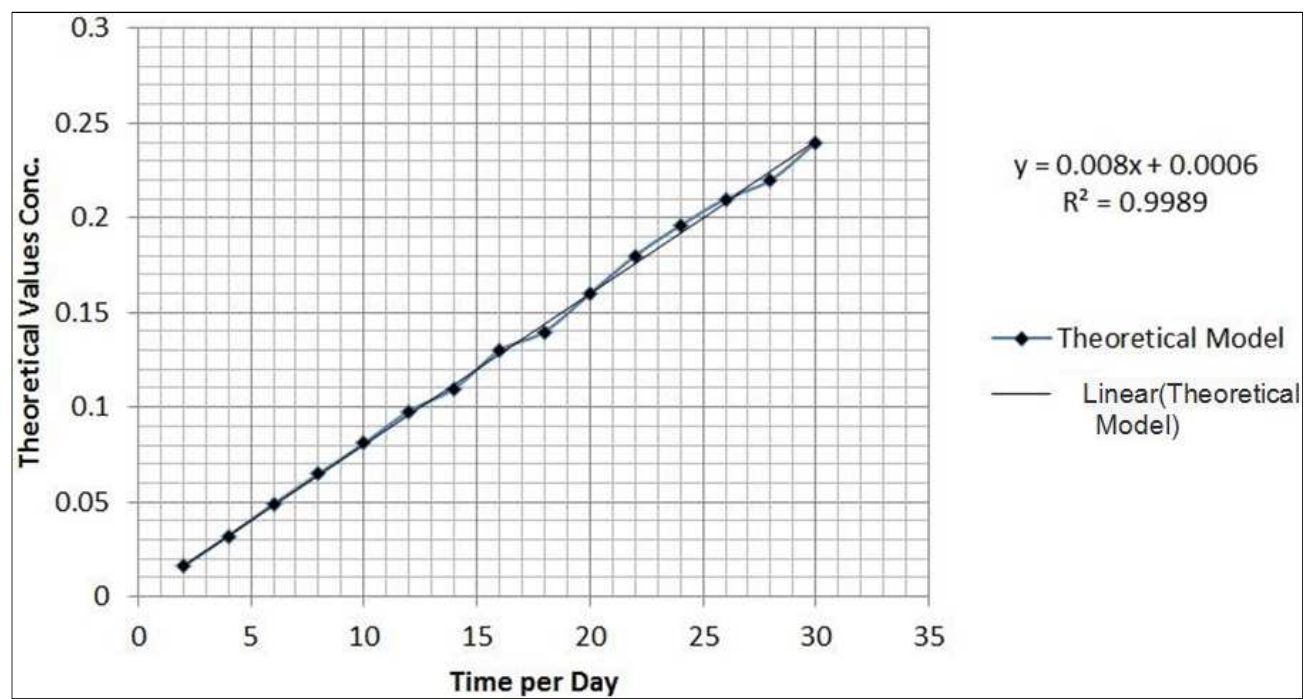

Figure 4.3. Theoretical Measured values of pathogen Concentration at Different depth.

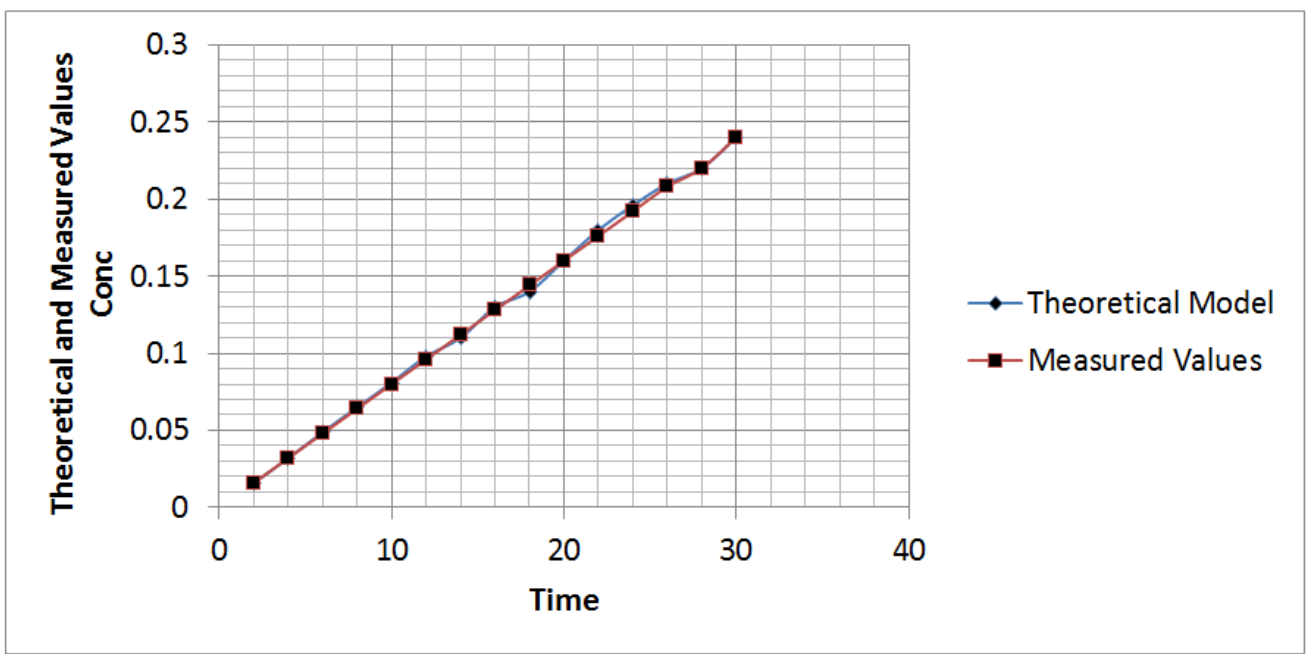

Figure 4.4. Theoretical Measured values of pathogen Concentration at Different depth.

The rapid migration and development of pathogen at shallow aquifers has been expressed in graphical representation of the devloped simulation model, such expression from figure one to eight show the exponetial phase of the microbes in the study area, homegenous condition of the microbes in all the graphical representation, it shows the rate of migration within the batch state of the formation, even if slight variation were expressed in few depths, it cannot in any way make any significant impact on the homogenous formation monitoring migration of pathogen in sand gravel formation, the study monitored the behaviour of the micobes in terms of linear phase migration in uniformed sand gravel deposition in caostal formation, this study were carried out by devloping a system that will expressed the behaviour of pathogen in homogeneous sand gravel in caostal area of abonnema, the model simulated produces theoretical values at differnt concentration, depth and time, such simulation from the developed model were compared with measure values from column experimental results at different location, both values developed a faviourable fits validating the derived model

\section{Conclusion}

The depositions of Fluid are influenced by structural stratification of the formation. Alluvium developing from sea deposition, it is structured under the influence of its geological setting that develops predominant homogeneous formation in some region of Abonnema The expressed condition generated lots of formation characteristics including influence from climatic conditions predominant in deltaic environment. The deposited homogenous formation in the study location experienced constant flow of potassium and lead under the influence of steady rate of flow in the formation. Some deposited substance apart from E.coli has been confirmed to deposit in some region of Abonnema influenced by Benin predominant formation through alluvium deposition. Unconfined beds were confirmed to develop slight in some region of Abonnema, depositing homogenous sand gravel formation including high degree of permeability. Dispersion influences were monitored based on high degree of permeability where E.coli and some inhibitors 
are deposited in fine and gravel formation. The study is essential since alluvium are predominant of homogeneous formation, it was found to deposit unconfined beds developing high dispersing rate of E.coli under the influence of homogenous fine strata. Experts will from the developed model manage shallow deposition of E.coli; this will be a guided baseline to monitor such pollution transport in coastal shallow bed in the study location

\section{References}

[1] Bradford, S. A. and M. Bettahar, 2005. Straining, attachment, and detachment of Cryptosporidium Oocysts in saturated porous media. J. Environ. Qual. (34), p. 469-478.

[2] Cameron, D. R. and A. Klute, 1977. Convective-dispersive solute transport with a combined equilibrium and kinetic adsorption model. Water Resour. Res. 13, 183-188.

[3] Corapcioglu, M. Y. and A. Haridas, 1984. Transport and fate of microorganisms in porous media: atheoretical investigation. J. Hydrol. 72, 149-169.

[4] Karim, M. R., M. W. LeChevallier, M. Abbaszadegan, A. Alum, J. Sobrinho, and J. Rosen, 2004a. Field testing of USEPA Methods 1601 and 1602 for coliphage in groundwater. AWWA Research Foundation. ISBN 1-58321-348-1.

[5] Matthess, G. and A. Pekdeger, 1988. Survival and transport of pathogenic bacteria and viruses ingroundwater. In Groundwater Quality, edited by C. H. Ward, W. Giger, and P. L. McCarty, pp. 472-482, John Wiley, New York, 1985.

[6] Medema, G. J., P. Payment, A. Dufour, W. Robertson, M. Waite, P. Hunter, R. Kirby and Y. Andersson, 2003. Safe drinking water: an ongoing challenge. In: Assessing microbial safety of drinking water: improving approaches and methods, Dufour et al. (eds.). World Health Organization, 2003.
[7] Pang. L., M. Close, M. Goltz, L. Sinton, H. Davies, C. Hall and G. Stanton, 2003. Estimation of septictank setback distances based on transport of E. coli and F-RNA phages. Environ. Int. (29), p. 907-921.

[8] Payment, P., M. Waite and A. Dufour, 2003. Introducing parameters for the assessment of drinkingwater quality. In: Assessing microbial safety of drinking water: improving approaches andmethods, Dufour et al. (eds.). World Health Organization, 2003. ISBN 924154630.

[9] Powelson, D. K., and A. L. Mills, 2001. Transport of Escherichia coli in sand columns with constantand changing water contents. J. Environ. Qual. (30), p. 238-245.

[10] Schijven, J. F. 2001. Virus removal from groundwater by soil passage. Modelling field and laboratory experiments. $\mathrm{PhD}$ Thesis. ISBN 90-646-4046-7. Posen and Looijen, Wageningen, The Netherlands.

[11] Simunek, J., K. Huang, M. Sejna, and M. T. van Genuchten, 1998. The HYDRUS-1D software packagefor simulating the one-dimensional movement of water, heat, and multiple solutes invariably-saturated media - version 2.0, IGWMCTPS-70, International Ground WaterModeling Center, Colorado School of Mines, Golden, Colorado, 202 pp.

[12] Tong, M. and W. P. Johnson, 2006. Colloid population heterogeneity drives hyper-exponentialdeviation from classic filtration theory. Environ. Sci. Technol., in press.

[13] World Health Organization, 2000-2003. Global Water Supply and Sanitation Assessment 2000 Report. http://www.who.int/docstore/water_sanitation_health/globasse ssment.

[14] Jan Willem Anton F 2007Transport of Escherichia coliin saturated porous media Published by A. A. Balkema Publishers, a member of Taylor \& Francis Group plc.www.balkema.nl and www.tandf.co.uk. 